\title{
FORMATION OF EDUCATIONAL AND COGNITIVE COMPETENCY OF JUNIOR SPECIALISTS IN THE PROCESS OF SELF-EDUCATIONAL ACTIVITY: EXPERIENCIAL ASPECT
}

10.36740/WLek202012118

\author{
Svitlana P. Palamar' ${ }^{1}$ Liudmyla A. Nazarenko ${ }^{2}$, Halyna 0. Vaskivska ${ }^{1}$, Liudmyla L. Nezhyva ${ }^{1}$, Nataliya N.Golota ${ }^{1}$, \\ Viktorija V. Zhelanova' \\ 'BORIS GRINCHENKO KYIV UNIVERSITY, KYIV, UKRAINE \\ ${ }^{2}$ MYKOLAIV REGIONAL INSTITUTE OF POSTGRADUATE EDUCATION, MYKOLAIV, UKRAINE
}

\begin{abstract}
The aim: The purpose is to elucidate the methodical system of formation of educational and cognitive competence of students of medical education institutions, the results of the research. Materials and methods: The approbation of the proposed methodology is analyzed, the results of the experiment were clarified. Using the methods of Student's mathematical statistics, the effectiveness of the methodical system of formation of educational and cognitive competence of students of medical education institutions was determined, the results are reflected in tables and calculations.

Results: With the purpose of solving educational and practical, scientific, educational and cognitive tasks, the types of activity of future junior specialists, which differ in the degree of obligatory fulfillment, are distinguished. It is shown that the realization of the cognitive principles of self-educational activity, which students perceive as their own internal need, is of great importance.

Conclusions: After investigation of the impact of students'self-educational activities on the formation of their educational and cognitive competence, we argue that it is the main component of the educational process, which requires a willful effort to overcome difficulties and is implemented through goal-setting, planning and staged implementation.
\end{abstract}

KEY WORDS: medical education, educational and cognitive competence, self-educational activity of students, competence approach, self-development of personality

Wiad Lek. 2020;73(12 p. I):2657-2663

\section{INTRODUCTION}

The priorities of modern education are defined in the normative documents of international conventions. They are the roadmaps for reforming Ukrainian science and moving towards integration into European communities. The National Doctrine on the Development of Education of Ukraine in the 21st Century identifies a priority task, which is to educate people in the spirit of responsible attitude to their own health and the health of others as the highest individual and social value [1]. The modernization of modern vocational education has led to increased requirements for the training of medical professionals. In the context of health care reforms, they must provide the skilled patient care, organize sanitary and epidemic regimens, take rehabilitation measures, be familiar with regulations, the latest manipulation techniques and medical technologies. All this requires an increase in the formation of educational and cognitive competence.

While striving for comprehensive personality development, teachers sometimes forget about the overload that causes neuroses of future junior specialists. Competently organized self-educational activities of students of the 1st year of medical colleges, observance of valeological requirements, familiarization with health preventive and educational measures are able to improve vocational training that responds to modern challenges. Therefore, medical and educational foundations of health are based on the knowledge of the person, his physiological and psychological characteristics. An important role in the formation of students' educational and cognitive competence is played by the understanding of the importance of improving their own theoretical knowledge and practical skills.

Instead, the realities of today are convinced that there are some contradictions between 1) the social need for competent individuals who are able to act practically, to apply their own experience in situations of professional activity, practice and insufficient readiness of college teachers to form such characteristics in students; 2) the level of cognitive skills, self-educational abilities of students of medical colleges and the complexity of the normative content of education; 3 ) the desire of young people to improve their skills, acquire skills to perform certain procedures, manipulations and lack of uniform technological standards for the practice of nursing care workers; 4) the objectively determined practical need for the development of educational and cognitive competence in the study of natural sciences and insufficient scientific and theoretical development of this problem in the field of theory and 
methodology of teaching. Such inconsistency requires attention to the purposeful designing of self-educational activity, formation of educational and cognitive competence of students of vocational education institutions, indicates the urgency of the problem of their self-development and necessitates the search for optimal methods, techniques, means of improving productive medical training. This is done by optimizing the educational process, creating the conditions for the search and project activities of freshmen.

Among the objective and subjective reasons that led to the development of a negative trend are the overload of educational programs, the lack of a comprehensive program of self-development and a holistic methodological and theoretical basis of the competence approach, partial introduction of new technologies, lack of attention to prestige profession. These factors complicate the process of comprehensive development of the individual and confirm the priority of the issue. Despite the urgency of the problem under study for medical colleges, they have not yet found their necessary coverage in the conceptual methodical development of the issue of improving medical education, scientifically grounded and practically tested technology of formation of educational and cognitive competence through self-educational activities.

\section{THE AIM}

Illuminate the methodological system of formation of educational and cognitive competence of students of medical educational institutions, submit the results of the research.

\section{MATERIALS AND METHODS}

The complex of methods is used in the work: general scientific (analysis, synthesis, comparison, systematization, generalization), empirical (observations, conversations, questionnaires), methods of mathematical statistics - at the stage of processing the results of pedagogical experiment, in particular to evaluate the efficiency and reliability of the results obtained.

\section{RESULTS AND DISCUSSION}

Self-education activities of students of the first year of medical college will ensure the effective formation of their educational and cognitive competence in the study of subjects of the natural cycle. The objectives of the study: 1) to formulate their own understanding of the defined concept on the basis of integrating scientific definitions of educational and cognitive competence; 2 ) to substantiate the structure of educational and cognitive competence as a personal and professional phenomenon; 3) summarize the results of the experiment.

On the best traditions of scientific thought development were considered the concepts of "competence" and the general basics of implementation of the competence approach N. Bibik, I. Zymna, O. Lokshina, O. Pometun, O. Ovcharuk, O. Savchenko, G. Selevko, N. Khomsky, V. Sharko, O.
Khutorsky and others. Various aspects of clarifying the nature and structure of competencies were developed by R. Oscarsson, J. Raven, and V. Hutmacher; methodological principles of development of educational and cognitive competences of students (I. Burgun, L. Blagodarenko, E. Bondarevska, V. Kraevskyi, etc.), study of the system of extra-auditory work (G. Andreeva, L. Kondrashova).

Today, the range of views on competence, competence approach and varieties of competences is multifaceted. In Germany, competence is considered on the basis of a cognitive approach, in France - multidimensional, in America - behavioral, in England - functional, in Belgium - multifunctional and personal, in Finland - active and personal. This makes it difficult to understand its content and the ability to develop measurement criteria. In scientific studies of the European education system, competence is interpreted as the ability of the individual to perceive and respond to individual and social needs, a set of attitudes, values, knowledge and skills. O. Ovcharuk views the interpretation of this concept through the lens of expert evaluation of the DeSeCo program participants, who define the competency concept as the ability to successfully meet individual and social needs, act and fulfill the tasks set [1]. The author distinguishes social, motivational, functional competences.

The concept of "competence", as developed by the International Standards Department for Learning, Achievement and Education, is defined as the ability to perform an activity, conduct a task or work, and includes knowledge, skills, attitudes that enable an individual to effectively act or perform those or other functions aimed at achieving certain standards in the professional field [2]. Considering the international experience, we consider it necessary to use active, competent and personally oriented approaches in the formation of educational and cognitive competence of students of medical colleges.

Types of competence are analyzed in detail in the researches of scientists. Thus, N. Bibik distinguishes the following: informational, social, educational-cognitive (methodological), vital (social-labor) [3]. This approach is in line with the educational goals formulated by UNES$\mathrm{CO}$, which emphasize the importance of learning how to acquire knowledge in order to master the profession, for a healthy lifestyle and adaptation in society.

Key competences are closely linked to human social life, aiming at the formation of basic skills. Thus, from the perspective of I. Zymna, the competency approach is in line with the humanistic values of education, focused on pragmatism. With this approach, the educational goal is transformed into one's own and is conceived in order to achieve a positive result. In addition, the scientist distinguishes between key competences relating to a) himself as a person, the subject of life; b) interaction of people; c) human activity, which manifests itself in all its types and forms [4]. Each of them has a number of equally important competences that are related to the individual and his activity, while acquiring personal traits, which confirms the importance of using activity-oriented, competent and personally-oriented approaches. 
The paradigm in the theoretical elaboration of judgments for our research is A. Khutorsky's view, he presents a list of key competences, which include value-semantic, general-cultural, educational-cognitive, informational, communicative, social-labor and personal ones [5]. The scientist focuses primarily on the scope and interests of the social individual. In this case, a competent approach promotes personal and social adaptation.

J. Raven understands the components of competency as the characteristics and abilities of people that enable them to attain personally meaningful goals, regardless of their nature and the social structure in which they live and work [6]. For this, it is necessary to create a studying environment that takes into account the conditions for identifying and developing the abilities of a future specialist who is able to perform self-analysis and check the effectiveness of his/her own activities.

On the basis of the works of N. Bibik, I. Zymna, J. Raven, A. Khutorsky, we distinguish educational and cognitive competence as basic for the formation of professionalism of future nurses, since basic skills and key qualifications can be acquired through motivation, personal abilities, self-education and self-development. In addition, this particular competence is fundamental, because in the process of studying, knowledge of the new is formed and all other competences are realizing. Let's consider attempts to define the term "educational and cognitive competence" in the educational field.

Educational and cognitive competence I. Burgun defines as the integrated capacity of the student, manifested in his ability to perform self-directed educational and cognitive activity, aimed at solving practical-oriented problems (household, professional), which is provided by his psychological, theoretical and practical willingness to it, which, in turn, is achieved through the formation and organization of educational activity [7].

Inasmuch as a key educational and cognitive competence is universal and belongs to both education and society, therefore S. Vorovschykov understands it as the level of realization of educational and cognitive activity, which corresponds to the system of values, principles and methods of cognition existing in the culture of society. The basic principles underpinning the formation of the specified competence, from the point of view of the scientist are the following: 1) actualization of meta-subject bases of the content of education; 2) strengthening the methodological component of the content of education; 3) ensuring the practical direction of education; 4) strengthening of the activity component; 5) personal orientation of the content of education [8]. For our research, the adherence to these principles means determining the content of the discipline, forming students' readiness to mastering knowledge, proficiency, skills in real life to solve educational and practical, practice-oriented and research tasks, the ability to independently use universal competencies in new situations oriented learning that involves attention to the individual, disclosure of his/her potential and a sense of the importance of his/her activities. In this case, the characteristic features inherent in educational and cognitive competence, we define the ones which are related to motivational, cognitive, value-semantic, behavioral reflexive aspects and motivational, developmental, activity and gnostic functions.

M. Galaguzova connects the educational and cognitive competence of bachelors with the methodological one, pointing to the students' ability to do scientific and cognitive and practical activities, the ability to reflect, which is manifested in the ability to analyze their own scientific activity, critical view and creative use of concepts [9]. Therefore, this competence contains, in addition to the effective use of professional knowledge, skills, aspirations, attitude to the case, taking into account the characteristics of the individual.

We consider the actual opinion of T. Salthouse, who distinguishes the concepts of "educational and cognitive competence" and "cognitive ability", in his belief, they differ in the type of cognition, evaluation, individual behavior of the research, perception and relevance of experience [10]. Based on the results of theoretical analysis of the approaches of scientists to the characteristics of educational and cognitive competence, we understand it as a set of competences of the student in the field of general, independent cognitive activity: knowledge and skills of goal setting, planning, analysis, reflection, self-esteem, as well as quality and result of activities in which the individual's ability to perceive and respond to individual and social needs is felt.

A pedagogical experiment was conducted to identify the effectiveness of the developed methodological system. It was attended by 985 students and 394 teachers of science in the Volyn, Rivne, Zakarpattia, Chernihiv, Odessa, Chernivtsi regions.

The pedagogical experiment consisted of three stages: 1) the diagnostic stage of the experiment; 2) the forming stage of the experiment; 3 ) the ascertaining stage of the experiment.

At the diagnostic stage the actual state of formation of educational and cognitive competence (E-CC) of students of medical colleges is established; the experience of teachers of natural sciences in the implementation of competent, active, personally oriented approaches in teaching practice is determined; the state of readiness of teachers to formation of educational and cognitive competence of future junior specialists is revealed; the reasons for the unpreparedness to carry out self-educational research activities by the recipients were determined, as well as ascertaining sections.

In the course of the experiment, the general content of the E-CC formation is outlined in the following components: a) motivational-oriented (a set of motives that encourage knowledge, acquisition of professional knowledge, experience of professional activity); b) essential (knowledge of the basic tendencies of development of a professional branch, conditions for success in the chosen specialty, mastering knowledge in natural disciplines, awareness and erudition of subjects of the natural science cycle, understanding of the essence of self-educational work, mechanisms of its manifestation, rational ways of performing individual specific activities); c) activity-connective (identification of 
volitional qualities, application of skills, experience, attitudes in planning, organization and regulation of self-educational activity, practical realization of its purpose and tasks); d) resultant-reflective (identification of students' skills to consciously reflect and adjust the results of the performance).

Such components make it possible to determine the conditions under which the training is successful: 1) creation of an appropriate learning environment;2) motivation; 3 ) desire for self-realization, self-improvement; 4 ) adaptation to professional-role social functions, socio-professional status; 5) compliance with the requirements of industrial discipline, the formation of self-regulation of behavior and activity; 6) a sufficient level of special training; 6) overcoming internal and external obstacles.

Checking the effectiveness of the developed technology of formation of educational and cognitive competence of students of medical colleges was carried out in the process of applying the comparative method of scientific research, the essence of which is to compare the results of experimental and control groups in the process of research work. Self-assessment and peer review data were evaluated using the following criteria and indicators:

1) motivational-value (internal motives: attitude to educational and cognitive activity, sensual needs of students to carry out research independent activity, to show interest in the profession, desire for self-development, to realize a high level of requirements, as well as external motives: prestige of the profession, social protection, material component);

2) knowledge (development of intellectual abilities, acquisition of knowledge and ways of solving educational-practical, practical-oriented, research tasks);

3) experiential activity (acquisition of experience and ways of mental activity, self-education, activation of students' extracurricular intellectual activity);

4) control-reflexive (application of methods of objective control of competently oriented training of future junior specialists, ability to objective self-assessment of students).

The levels of development of educational and cognitive competence can be determined as high, sufficient and average. A high level is indicated by the ability of future junior specialists to express interest in the profession; independently develop, design and implement an individual plan / route of self-educational activity; develop educational and cognitive competences; obtain the necessary information; critically process and use it; elaborate, solve participation in project activities, reflections; consider the errors and conduct the correction of results. Sufficient level has the following markers: students show a desire for self-development; able to increase the level of educational and cognitive competences; able to participate in the project work with the help of the routes of educational activity developed by the teacher; obtain the necessary information; has the skills of self-analysis. The average level is indicated by the need in the teacher's help in classroom and extra-curricular work; activation of students' intellectual activity; control of students' research independent activity; application of methods of objective control over the quality of competently oriented training of youth.
At the formative stage of the experiment, a methodological model of the formation of educational-cognitive competence (E-CC) of students of medical colleges was developed on the basis of independent cognitive, research activity through the use of ICT tools. The formation of educational and cognitive competence was carried out on the basis of various activities of future junior specialists, which differed in the level of compulsory: a) compulsory, determined by the curricula (homework, preparation for lectures, seminars, practical classes); b) recommended (participation in work of intellectual circles, scientific conferences, preparation of reports, abstracts, peer review of works, etc.); c) initiated (participation in professionally oriented competitions, Olympiads, quizzes, production of visualization). By the level of expression of creativity: a) constructive (development of technological maps, supplementing the lectures of the teacher, solving problematic educational-practical, practice-oriented and research tasks); b) research (experimentation, theoretical research); c) creative (participation in project work, performance of creative tasks).

The principles of cognition are based on the proposed technology: objectivity, concreteness, unity of dialectic and logic, practice, comprehensive consideration, reflection.

The following stages have been determined for conducting the design phase of the experiment: I - organizational and motivational, II - active, III - productive. The results of the ascertaining stage of the pedagogical experiment: after the introduction of the developed technology, the level of students' motivational sphere increased. In order to obtain reliable data during the experiment, the following requirements were met: the assessment in the experimental and control groups was carried out simultaneously, the content of the control was the same and corresponded to the state requirements for students' educational achievements, the same criteria were applied to assess the levels of development of educational and cognitive competences.

In order to study the significance of motives that motivate students to self-educational activity, the methodology of their evaluation was developed by M. Vilensky [11]. Analyzing the consolidated data, we found that in the control groups (CG) there is a slight increase in the level of formation of the motivational-oriented component. Among the students of the experimental groups, the dominant motives in self-study were: cognitive motives (0.73), motives of research activity (0.75), motive of manifestation of personality in the profession (development of self-realization in the profession) (0.74) (Table I).

Comparative results of essential and activity-connective components of EG (beginning of the experiment / end of the experiment) are shown in Figures 1 and 2. As a result of a detailed analysis of the academic success of the subjects of natural science training of students of experimental groups after the implementation of the experiment revealed that the average score of success is 4.0, and qualitative assessment $71.5 \%$, indicating an increase (25\%), which demonstrates the effectiveness of the proposed technology. The average of the CG student achievement score is 3.55 (46.6\%), which is 0.45 less than the same of EG student performance (24.9\% 
Table I. Comparative indicators of the formation of a motivational-oriented component, estimated by the motivational-value criterion in control and experimental groups

\begin{tabular}{|c|c|c|c|c|c|c|}
\hline \multirow[t]{2}{*}{ № } & \multirow[t]{2}{*}{ Motives } & & \multicolumn{2}{|c|}{$\begin{array}{c}\text { Formation levels before the } \\
\text { experiment }\end{array}$} & \multicolumn{2}{|c|}{$\begin{array}{c}\text { Formation levels after the } \\
\text { experiment }\end{array}$} \\
\hline & & & Grade & Self-esteem & Grade & Self-esteem \\
\hline \multirow{2}{*}{1} & \multirow{2}{*}{$\begin{array}{l}\text { Attitude towards educational and cognitive activity, } \\
\text { manifestation of desire of self-development, } \\
\text { realization of high level of own requirements. }\end{array}$} & CG & 0,52 & 0,76 & 0,56 & 0,63 \\
\hline & & EG & 0,59 & 0,8 & 0,71 & 0,75 \\
\hline \multirow{2}{*}{2} & \multirow{2}{*}{$\begin{array}{l}\text { Sensual needs of students to carry out } \\
\text { research independent activity. }\end{array}$} & CG & 0,52 & 0,74 & 0,56 & 0,62 \\
\hline & & EG & 0,56 & 0,79 & 0,72 & 0,78 \\
\hline \multirow{2}{*}{3} & \multirow{2}{*}{$\begin{array}{l}\text { Identification of personality of interest, } \\
\text { self-realization in future profession. }\end{array}$} & CG & 0,45 & 0,85 & 0,55 & 0,63 \\
\hline & & EG & 0,50 & 0,87 & 0,70 & 0,78 \\
\hline \multirow{2}{*}{4} & \multirow{2}{*}{ External motives (social motives). } & CG & 0,57 & 0,82 & 0,71 & 0,76 \\
\hline & & EG & 0,59 & 0,86 & 0,78 & 0,81 \\
\hline \multirow{2}{*}{5} & \multirow{2}{*}{$\begin{array}{l}\text { The final indicator of the formation of } \\
\text { a motivational-oriented component. }\end{array}$} & CG & 0,52 & 0,79 & 0,59 & 0,66 \\
\hline & & EG & 0,56 & 0,83 & 0,73 & 0,78 \\
\hline
\end{tabular}

Table II. Comparative table of the formation of educational and cognitive competences in subjects of natural science training of students of the 1st year (specialization - nursing, base 11 classes)

\begin{tabular}{|c|c|c|c|c|c|}
\hline \multirow{2}{*}{ Knowledge } & & \multicolumn{2}{|c|}{ Before the experiment } & \multicolumn{2}{|c|}{ After the experiment } \\
\hline & & Grade & Self-esteem & Grade & Self-esteem \\
\hline \multirow{2}{*}{$\begin{array}{c}\text { Bioinorganic and bioorganic } \\
\text { chemistry, physiology }\end{array}$} & EG & 0,53 & 0,70 & 0,55 & 0,71 \\
\hline & CG & 0,48 & 0,66 & 0,63 & 0,66 \\
\hline \multirow{2}{*}{$\begin{array}{l}\text { Human anatomy, pathomorphology, } \\
\text { pathophysiology. }\end{array}$} & EG & 0,44 & 0,58 & 0,75 & 0,77 \\
\hline & CG & 0,39 & 0,60 & 0,45 & 0,50 \\
\hline \multirow{2}{*}{$\begin{array}{c}\text { Medical chemistry, pharmacology } \\
\text { and medical prescription. }\end{array}$} & EG & 0,52 & 0,79 & 0,78 & 0,80 \\
\hline & CG & 0,50 & 0,73 & 0,56 & 0,64 \\
\hline \multirow{2}{*}{$\begin{array}{c}\text { Fundamentals of biological physics } \\
\text { with medical equipment. }\end{array}$} & EG & 0,47 & 0,67 & 0,76 & 0,81 \\
\hline & CG & 0,45 & 0,63 & 0,54 & 0,64 \\
\hline \multirow{2}{*}{ Final score. } & EG & 0,49 & 0,69 & 0,71 & 0,77 \\
\hline & CG & 0,46 & 0,66 & 0,54 & 0,61 \\
\hline
\end{tabular}

difference). In the results provided in the Table II, the significant qualitative differences in the success of the formation of educational and cognitive competences in science subjects 0.71 (EG) against 0.51 (CG) is shown.

Figure 3 shows that the level of self-education in EG, unlike in CG, is much higher. At the same time, according to the results of questionnaires and evaluations for participation in the project activity, the number of EG students with high and sufficient levels as a result of the experiment has increased. The planners were pleased to participate in the search, research and creative work, which affected the motivation for learning and the growth of their skills.

The results obtained were proved using the methods of Student's mathematical statistics. To test the assumption of the effectiveness of experimental technology for the formation of educational and cognitive competence (E-CC) students of medical colleges, put forward two hypotheses: the first $-\mathrm{H}_{0}-$ the differences between the levels of E-CC in the experimental and control groups are accidental, therefore, the formation stage of the experiment was not successful; the second $-\mathrm{H}_{\mathrm{w}}$ - the differences between the levels of E-CC formation in the experimental and control groups are significant. The values were calculated using the formulas:

$$
t_{E G}=\frac{\left(\bar{\xi}-a_{0}\right)}{\frac{s}{\sqrt{n}}}, \quad \bar{\xi}=\frac{1}{n} \sum_{i=1}^{n} \xi_{i}, \quad s^{2}=\frac{1}{n-1} \sum_{i=1}^{n}\left(\xi_{i}-\bar{\xi}\right)^{2}
$$

Using the Student's test, the following values were obtained: sample averages $\overline{\mathrm{x}}=0,53 ; \bar{\gamma}=0,71$; selective variances $\mathrm{s} \frac{2}{C G}=0,00105 ; \mathrm{s} \frac{2}{\mathrm{EG}}=0,00173$; asymmetry coefficient $\mathrm{A}_{C G}=0,10 ; \mathrm{A}_{\mathrm{EG}}=0,14$; excess factor $\mathrm{E}_{C G}=-0,07 ; \mathrm{E}_{\mathrm{E} G}=-0,19$.

The obtained values of asymmetry coefficients and excess factor are slightly different from the zero values, characterizing the normal rule of distribution of estimates, so we believe that the estimates in CG and EG are subject to the rule of distribution, to test the formed hypotheses of the use of the Student's criterion is appropriate. Given that selective variances are different, we calculate Student's statistics according to the formula: $\overline{\mathrm{x}}=\frac{1}{N c g} \sum_{\mathrm{i}=\mathrm{i}}^{N c g}$ Xi. To test the hypotheses, we use the F-test (Fisher test) and statistics $g=S \frac{2}{C G} / \mathrm{S} \frac{2}{\mathrm{EG}}$.

As the result we obtain $g=-34,94 ; \quad t_{v, 1-a / 2}=-0,61$. 


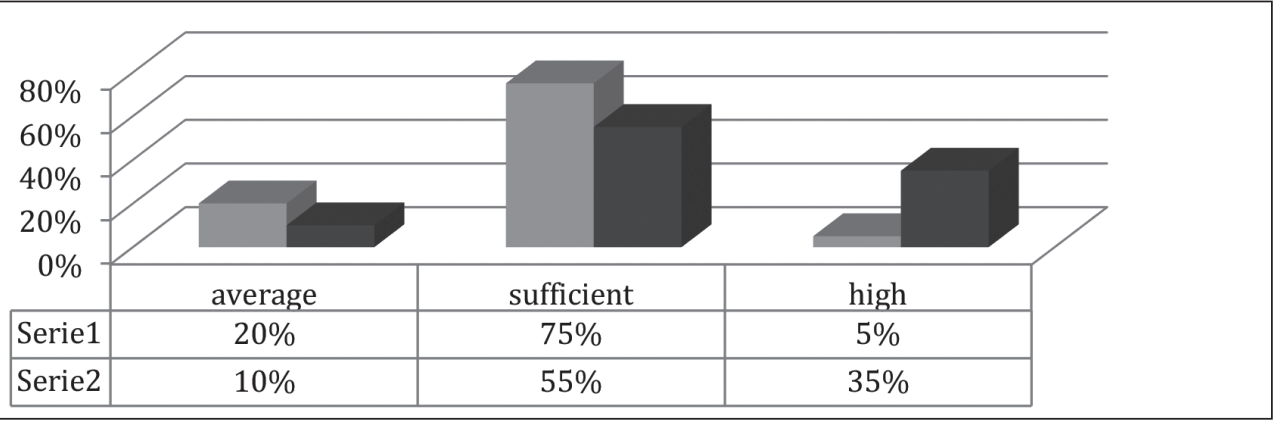

Fig. 1. Comparative results of the formation of the essential component of students' educational and cognitive competence (beginning of the experiment).

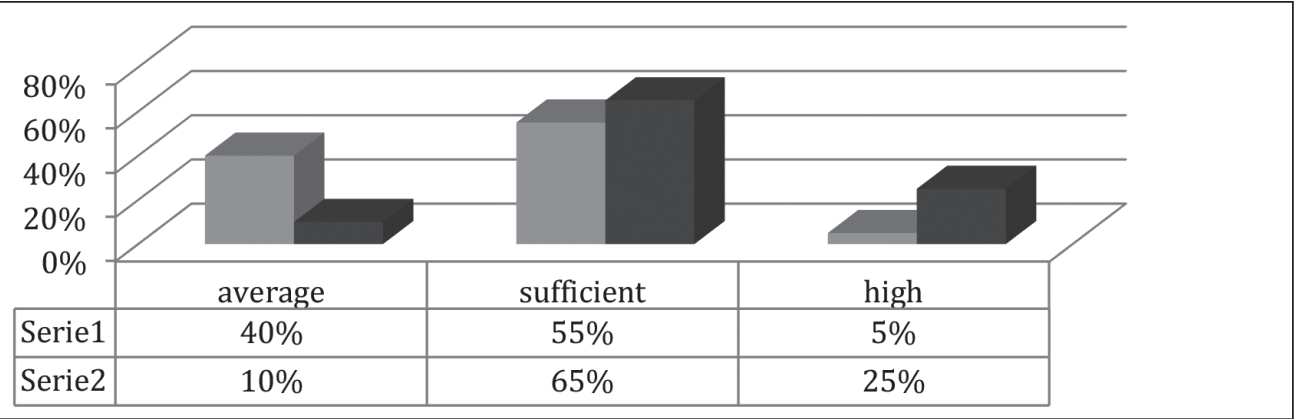

Fig. 2. Comparative results of the formation of the essential component of students' educational and cognitive competence (end of the experiment).

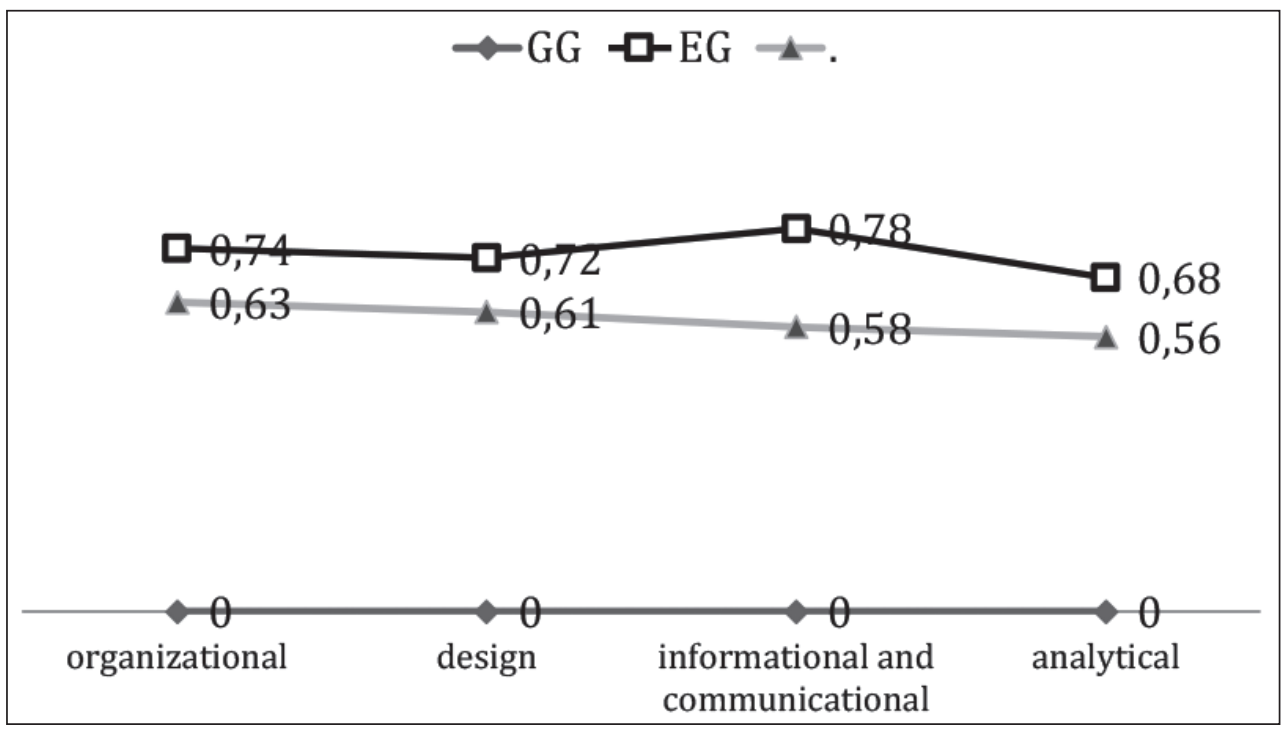

Fig. 3. Level of self-education.

Condition $|g|<t_{v, 1-a / 2}$, is not fulfilled. The null hypothesis was false, and the averages of the two samples belong to different sets. Thus, the sampled comparisons cannot be considered homogeneous. This indicates a significant difference between the levels of E-CC formation of CG and EG students, which, in turn, proves the statistical significance of the difference in the indicators of the control and experimental groups obtained at the ascertainment stage of the experiment. The analysis of the obtained results confirmed the assumption that the differences between the levels of E-CC formation in the experimental and control groups are significant. This testifies to the positive dynamics of the level of development of educational and cognitive competence, and therefore the successful conduct of the experiment and the achievement of the goal.

\section{CONCLUSIONS}

Summarizing the results of the study on the testing of the methodological system of formation of educational and cognitive competence based on the study of subjects of the natural science cycle of students of medical education institutions gives grounds for formulating conclusions: 
1. Based on the integration of scientific definitions of educational and cognitive competence, the personal understanding of the concept is formulated; the structure of educational and cognitive competence as a personal and professional phenomenon is substantiated.

2. It is proved that educational and cognitive competence is a dominant key competence in the education of students of medical colleges, because it allows the formation of other competences, it promotes the personal and professional development of students.

3. These characteristics make it possible to form a scientifically grounded idea of the specificity and professional training of the future junior specialist with the developed educational and cognitive competence as a qualified nurse, argue that the formation of educational and cognitive competence occurs in the process of becoming an individual practice-oriented training.

4. The results of the pedagogical experiment showed an increase in the level of educational and cognitive competence formation of students of medical colleges, which confirms the effectiveness of the developed methodological system and the expediency of its introduction in the educational process.

Prospects for further research of the problem are to develop and substantiate the theoretical and methodological foundations for the development of professional competence, determine the conditions for creating a favorable learning environment.

\section{REFERENCES}

1. Ovcharuk 0. Kompetentnosti yak kliuch do onovlennia zmistu osvity. Stratehiia reformuvannia osvity v Ukraini: rekomendatsii z osvitnoi polityky [Competences as the key to update the content of education. Strategies for reforming education in Ukraine: recommendations on educational policy]. Kyiv: «K.I.S.». 2003: 296.

2. Spector J. M. Competencies for online teaching. ERIC Digest. In: Spector J.M. Clearinghouse on information and Technology Syracuse University NY. New York. 2001:1-3.

3. Bibik N.M. Perevahy i ryzyky zaprovadzhennia kompetentnisnoho pidkhodu v shkilnii osviti [Advantages and risks of introducing a competency-based approach in school education]. Ukrainskyi pedahohichnyi zhurnal. 2015; 1: 47-58.

4. Zimnyaya I.A. Klyuchevye kompetentnosti kak rezultativno-celevaya osnova kompetentnostnogo podxoda v obrazovanii [Key competencies as an effective-target basis of a competence-based approach in education]. Moskva: Issledovatelskij centr problem kachestva podgotovki specialistov. 2004: 42.

5. Xutorskoj A. Texnologiya proektirovaniya klyuchevyx i predmetnyx kompetencij: Doklad na otdelenii filosofii obrazovaniya i teorii pedagogiki RAO 23 aprelya 2002 [Technology for designing key and subject competences: Report at the Department of Philosophy of Education and Theory of Pedagogy of the Russian Academy of Education from April 23, 2002]. Centr «Ejdos». http://www.eidos.ru/ journal/2005/1212.htm
6. Raven D. Kompetentnost v sovremennom obshhestve: vyyavlenie, razvitie i realizaciya [Competence in moderm society: detection, development and realization]. Moskva: Kogito-Centr. 2002: 396.

7. Burgun I.V. Teoretyko-metodychni zasady rozvytku navchalnopiznavalnykh kompetentsii uchniv osnovnoi shkoly v navchanni fizyky [Theoretical and methodological principles of development of educational and cognitive competencies of primary school students in studying physics]. Kyiv. 2015: 44.

8. Vorovshhikov S.G. Uchebno-poznavatelnaya kompetentnost starsheklassnikov: soderzhanie, struktura [Educational and cognitive competence of high school students: content, structure]. Pedagogicheskie issledovaniya. 2019: 36-38. http://www. cyberleninka.ru/article/n/uchebno-poznavatelnaya-kompetentnoststarsheklassnikov-sostav-i-struktura

9. Galaguzova M.A., Doroxova T.S. K voprosu o nauchno-issledovatelskoj deyatelnosti bakalavrov i magistrov [0n the issue of research activities of bachelors and masters].2019. https://cyberleninka.ru/article/v/k-voprosuo-nauchno-issledovatelskoy-deyatelnosti-bakalavrov-i-magistrov

10. Salthouse T. A. Theoretical Perspectives on Cognitive Aging New York: Psychology Press. 1991: 488.

11. Vilenskij M.Ya., Obrazcov P.I., Uman A.I. Texnologii professionalnoorientirovannogo obucheniya $v$ vysshej shkole [Technologies of vocational education in higher education]. Moskva: Pedagogicheskoe obshhestvo Rossii. 2002: 275.

\section{ORCID and contributionship:}

Svitlana Palamar: 0000-0001-6123-241X ${ }^{A, D, F}$

Liudmyla Nazarenko: 0000-0001-6560-5252 A, B, C

Halyna Vaskivska: 0000-0002-8714-8512 ${ }^{A, E, F}$

Liudmyla Nezhyva: 0000-0001-9520-0694 ${ }^{\mathrm{E}}$

Viktorija Zhelanova: 0000-0001-9467-1080 ${ }^{\mathrm{B}}$

Nataliya Golota: 0000-0003-3748-753X ${ }^{E}$

\section{Conflict of interest:}

The Authors declare no conflict of interest.

\section{CORRESPONDING AUTHOR \\ Svitlana Palamar}

Pedagogical Institute of Boris Grinchenko University

18/2 I.Shamo Blvd, 01601 Kyiv, Ukraine

tel: +380507444635

e-mail: svetlana_03@ukr.net

Received: 14.04 .2020

Accepted: 28.09 .2020

A - Work concept and design, B - Data collection and analysis, C - Responsibility for statistical analysis,

D-Writing the article, $\mathbf{E}$-Critical review, $\mathbf{F}$ - Final approval of the article 